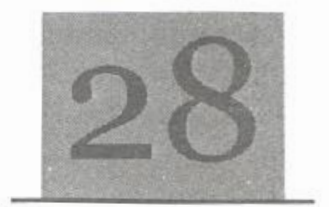

\title{
Impact of climate change on brackish water aquaculture development in the coastal areas of the Niger Delta
}

\author{
Akinrotimi, O. A./Edun, O.M.
}

\begin{abstract}
The issue of climate change has generated a lot of concern umang the general public in Niger Delta region in recent lime. It has been described in different ways by many people bused on their views perception und understanding. However, little considerations have been given to the impact of climate change on brackish water aquaculiure in the coastai areas of Niger delta. This paper therefore review critically, hased on existing literature and field experience, the causes of climate change, impact of climate change an aquaculture production such as: increase in temperature, flooding of ponds, increase in water turbidity, heavy siltation of pond bottom, introducrion of new species, collapse of farms infras/ructure and fuctuations in salinity levels. Also, various adiptation and mitigation strategies that will ameliorate the impact of climate change in aquaculture operations, namely: reduction in human activities that are inimiral to stable climate, selection of good site suitable for fish farming, provision of shating materials for fish cultured in tanks, raising of pond dykes, good management practices and improvement of monitoring and early warning systems, are explicitly elucidated. As these strategies will go a long way in minimizing the impact of this menace, in the brackish water zone of the region. Moreover, efforts should he made by relevant institutions and agencies tu come up with coordinated plans and policies that will rechuce the effects of climate change on brackish water aquaculture in the coastal areas of Niger Delta.
\end{abstract}

Keywords: Climate, fish, coastal environment, fish furming, Niger Deita.

\section{Introduction}

7 he Niger Delta is situated in the Atlantic coast of southern part of Nigeria and is one of the largest delta land form in the world, with vast coastal plain, rich biodervisity and abundant reserve of mineral resources (Akinrotimi, 2012). The region is known to have many streams, plethora of rivers and numerous tributaries which flow into the Atlantic Ocean through the Gulf of Guinca (Mangut and Egbefo, 2010). One of the unique features of this zone is its large expanse of coastal areas (Figure 1), which include saline swamps, creeks and estuaries, which form an integral part of the region (Table 1).

Table 1: Classification of the Niger Delta

\begin{tabular}{l|l}
\hline Zone & Area $\left(\mathrm{km}^{2}\right)$ \\
\hline Low land area & 7,400 \\
\hline Fresh water swamp & 11,700 \\
Saline swamp & 5,140 \\
\hline Rivers & 679 \\
Sand Barrier Islands & 1,000 \\
\hline Estuaries & 688 \\
\hline
\end{tabular}

Source: Ashton-Jones et al. (1998)

These coastal zones are dynamic in nature and the processes that occur within them provide diverse and useful ecosystem that are essential for the populace utilization (Kay and Alder, 2005). These areas are highly productive with significant biological diversity, rich fishery resources and important sea bed minerals (Cummins et al., 2005). Moreover, the region has a good capacity of supporting a large array of flora and fauna, with a good vast land and water resources that can adequately sustain a wide range of fish farming practices such as brackish water aquaculture (Akinrotimi et al., 2010a). 
Generally, Aquaculture like many other farming activities depends on the usc of natural resources such as water, land and suitable cnvironmental factors, as production of fish in any locality is driven by these factors (Jamu and Ayinla, 2003). The constant dynamic status of the coastal areas of Niger Delta has made it easier for it to be influenced by numerous human activities and natural phenomenon such as oil explorative and industrial activities, building, dredging, land reclamation and incidence of climate change. The concept and perception of climate change varies significantly among fish farmers in the brackish water zone. This has generated a lot of concern over the last decade. This has been defined and interpreted in so many ways, with the reality accepted by many and refuted by few people among the populace dwelling in these areas (Lomburg, 2007; Akinrotimi et al., 2010b)

Conversely, it is generally belicved that livelihoods of the people in the coastal arcas will be affected in one way or the other by climate change and one major way will be food production system in the natural environments

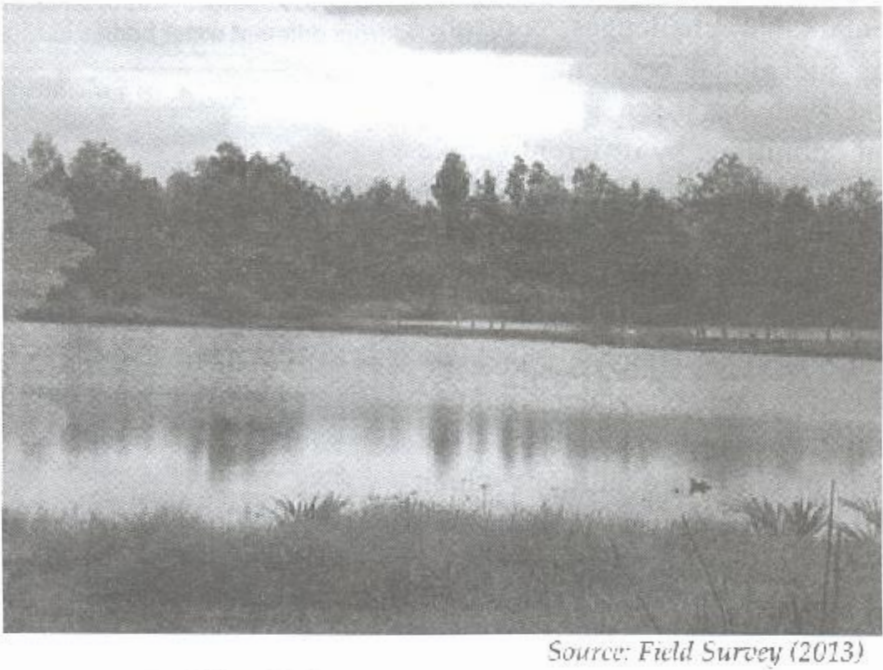

Fig. 1: A typical Niger Delta coastal environment. (IPCC, 2007). Climate change is expected to have a high impact on food securily. This may specifically affect Niger delta, sinee predictions indicate that the climale in the region may be subjected to morc extreme conditions and food security is already at risk in many parts of the region. It is very crucial to note that little considerations have becn given to the impacts of climate change on aquaculture. The responsible management of the resources and ecosystem upon which this important sector depends is a major challenge for world food security (Desilva and Soto, 2009). At the same time, fish farming activities arc being threatened by some external factors such as pollution, run offs and land use transformation process, a competing aquatic resources upon which the impacts of climate could have a compounding effect (Aye et al., 2007).

There is a strong scientific evidence of the incidence of climate change in Niger delta. However, information on its impact on brackish water aquaculture, a common practice in the coastal area of Niger delta is limited. This paper therefore reviewed critically the meaning, importance and impacts of climate change on brackish water aquaculture production. Also various strategies for mitigating the effects of these were clearly elucidated. This will provide vital information to fish farmers on various aspects of their vulnerability to the phenomena of climate change and possible strategies for adaptation.

\section{Brackish Water Aquaculture Production}

Table 2: Culturable fin and shellfish species in brackish water zone of Niger Della

\begin{tabular}{l|l|l}
\hline Species & Market value & Potential Yield \\
\hline Fin fishes & Very good & Very high \\
Tilapia guineensis & Low & Very high \\
Sarotherodon melonotheron & Very good & Low \\
Lutjanus goreensis & Good & Very high \\
Mugil cephalus & Good & Moderate \\
Liza falcip nnis & Good & Moderate \\
L grandisquamis & Low & Moderate \\
Megalops atlanticus & Very good & High \\
Chrysichthys migrodigitatus & Low & Low \\
Pomadysis jubelini & & \\
Shell fishes & Good & Very high \\
Crassostrea gasar & Good & Culture stlll experimental \\
Tympanotronus fuscatus & God & Culture still experimental \\
Anadara senilis & Very good & Very high \\
Penaeus monodon & Good & Culture still experimental \\
\hline Thais coronata & & \\
\hline
\end{tabular}

Source: Anyanwu et al. (2007)

Brackish water fish farming is a system of aquaculture that focuses on the production of quality fin and shell fishes that are found in the creeks, lagoons and estuaries through rational rearing (Akinrotimi et al., 2011). In Niger Deita, the practice of brackish water aquaculture is viable, because of large expanse of saline mangrove swamps suitable for development of commercial fish farming. The potential of brackish water aquaculture production in Niger Delta is tremendous, because of numerous culturable species of fish that abound in the region (Table 2).

These species easily moves from brackish to marine or fresh water depending on the month of the year (Akinrotimi 2009a). Moreover, Ezenwa (2006) reported that the Niger Delta region can raisc aquaculture production to about $1.200,000$ metric tons of fish (Table 3), and further observes that the region can actually be the food basket of the nation if proper attention is given to the area. In addition to culture of fin fishes, there are numerous shell fishes such as oysters, shrimps, clams, cockles and periwinkles, these are extremely abundant in the brackish water zone and can be cultured with minimal capital input in most communities located the coastal areas (Ansa and Bashir, 2007; Akinrotimi et al., 2009b). Despite the tremendous potential of brackish water aquaculture in this region, there are myriads of problems facing the development of aquaculture production in this region, slowing down the pace of its advancement, one of such challenges in recent times is climate change (Akinrotimi, 2012). 


\section{Incidence of Climate Change in the Niger Delta}

Climate change is one of the most remarkable challenges confronting the global community today and such has been given different definitions by different people based on their perception and the way it affects them (Ifeanyi Obi et al., 2012). However, the most universal definition was the one by intergovernmental panel on climate change, which defined climate change, as a change in the state of climatic conditions which can be measured and identificd, through changes in the mean of its properties that persists for a period of time. It also refers to any change in climate over a period of time as a result of anthropogenic or human activity (IPCC, 2007). The subject of climate and predicted impacts on the environment and socioeconomic system now constitute one of the most devas-

Table 3: Potential yield of aquaculture production from different water bodies in Niger Delta

\begin{tabular}{lc}
\hline Water body & Potential yield (mt/yr) \\
\hline Fresh water & 500,000 \\
\hline Brackish water & 400,000 \\
Marine water & 300,000 \\
\hline Total & $1,200,000$ \\
\hline
\end{tabular}

Source: Anyantos et al. (2007)

Table 5: Level of knowledge about climate change impacts in the coastal area of Niger Delta

\begin{tabular}{lll}
\hline Knowledge level & Freq. & $\%$ \\
\hline None & 25 & 20.8 \\
Low & 63 & 52.5 \\
High & 20 & 16.7 \\
Very High & 12 & 10 \\
Total & 120 & 100 \\
\hline \multicolumn{4}{c}{ Surrce: Fietd Surpey, $(2013)}$.
\end{tabular}

Table 4:Awareness of climale change impacts among fish farmers in Niger Delta.

\begin{tabular}{lcc}
\hline Awareness & Frequency & $\%$ \\
\hline Yes & 99 & 82.5 \\
No & 17 & 14.2 \\
Indifferent & 4 & \\
Total & 120 & 100 \\
\hline \multicolumn{4}{c}{ Source: Fiela Survey (2013). }
\end{tabular}

Table 6: information sources on climate change to fish farmers in the coastal area of Niger Delta.

\begin{tabular}{l|c|c|}
\hline Sources & Frequency & Percentage \\
\hline Commercial effect & 1 & 0.83 \\
Internet & 28 & 6.67 \\
\hline Religions bodies & 1 & 0.83 \\
\hline Friends'relations & 4 & 3.33 \\
\hline Personal experience & 45 & 37.5 \\
Newspapers & 10 & 8.33 \\
\hline Radio/television & 30 & 25.0 \\
None & 21 & 17.5 \\
\hline Total & 120 & 100.00 \\
\hline \multicolumn{3}{|c|}{ Source: Fieid Surzey, $(2013)$}
\end{tabular}

tating environmental problems facing humanity.

In a recent survey conducted by the author recently, the level of awareness of the impact of climate change especially among fish farmers is very high (Table 4). Although many of them do not have the full knowledge of the impacts brought about by climate change (Table 5). Also, many of the fish farmers came to know about this, through personal experience and mass media (Table 6), due to some negative occurrence caused by climate change, which they have experienced on their farms in recent times.

\section{Causes of Climate Change}

There are four major causes of climate change namcly: astronomical causes, volcanic eruptions, variations in solar output and human activity, among these, human activity has been recognized as the most prominent factor responsible for climate change (IPCC, 2001). This normally happens through the emissions of green house gases (mainly carbon dioxide, methane, halocarbon and nitrous oxide). In Niger Delta region, human activity changes the amount of green housc gases in the atmosphere in three important ways:

- Burning of fossil fucls: When fossil fuels such as coal, wood and petrolcum products burn, they release green house gases, also human activities such as driving automobiles, cooking food, bush burning, gas flaring and industrial operations equally releases these obnoxious, gases into atmosphere (Anyadike, 2009). In Niger Delta, oil explorative activities are very common and predominant. One major way this industry is impacting on the climate of the region is through gas flaring. Niger delta is reported to have over one hundred and twenty three gas flaring sites scattered all over the region, consequent of oil exploration, making the Niger Delta one of the highest emitters of green house gases in Africa (Akinro et al., 2008).

- Removal of mangrove forest: Mangrove forest is an important segment of the ecosystem in the coastal areas of Niger Delta; it serves many purposes, which ranges from stabilization of coastal environment to nursery for some shell fish and filtration of nutrient and sediments (James, 2008). The area covered by mangroves is influenced by a number of factors such as land position, rainfall pattern, sea level, sedimentation, storms and tidal regime. Removal of mangrove forests, where forests are cut down faster than they are replaced is a major contributor to climate change (James et al., 2007). In Niger Delta, the loss of mangrove is a major cause of climate change (Figure 2). The mangrove that was hitherto more than 1,000, 000 hectares had been reduced to 977, 700 hectares. Aggressive utilization for fire wood, clearing of new site for building or road construction and procurement of oyster spat(attached to mangrove root) has been majorly responsible for its exploi-

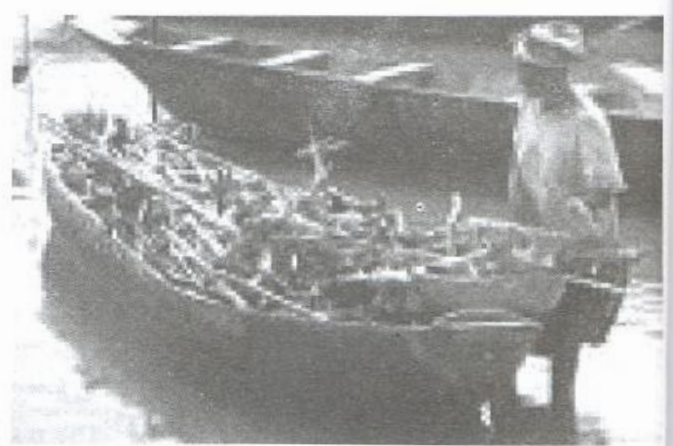

Fig. 2: Mangroves removal from coastal areas of Niger Delta. 
tation (Idowu et al., 2011). Depletion of mangroves has reduced the stabilization of ecosystem and further made the coastal arcas prone to the effects of climate change (Akinrotimi 2012).

- Increasing population: There is population explosion in most of the Niger Delta states, as a result of the assumcd lucrative opportunities in oil and gas industry. This phenomenon has led to increase in human activity, which invariably has led to more emissions.

\section{Impacts of Climate Change on Brackishwater Aquaculture}

On the issue of climate change, not all climatic changes are likely to have impact on aquaculture directly or indirectly (Desilva and Soto, 2009). In Niger Delta, the impact of climate change on fish farming activities can not be attributed to one single factor of climate change, it is usually a combination of two or more factors producing effects at a particular time. The impact of climate change in any area depends mainly on various factors such as: level of pollution, season, location, population and some level of industrial activities. Some of the impacts of climate change on aquaculture development in the coastal areas of Niger Delta are highlighted below:
Table 7: impact of climate change commonly experienced by fish farmers in the coastal areas of Niger Delta.

\begin{tabular}{l|c|c}
\hline Impact & Freq. & $\%$ \\
\hline Excessive temperature & 5 & 4.17 \\
\hline Flooding & 60 & 50.0 \\
\hline Introduction of new fish species & 2 & 1.67 \\
Irregular tidal regime & 7 & 5.83 \\
Introduction of new plant & 3 & 2.5 \\
\hline Damaging of pond dyke and sluicegate & 30 & 25.00 \\
Excessive garbage in the ponds & 3 & 2.5 \\
Water turbidity/siltation of pond & 10 & 8.33 \\
Total & 120 & 100.00 \\
\hline
\end{tabular}

- Increase in temperature: Fish like other aquatic animals are poiklothermic i.e. their internal temperature are regulated and controlled by their external surroundings. Therefore, any change in the temperature will have a significant effect on their general metabolism, growth and adaptive capacily in the culture medium. In Niger Delta, the bulk of aquaculture productions are from earthen pond, concrete and plastic tanks culture system. The increase in air temperature will cause increase in vaporization in these rearing facilities. Morcover, increased temperature will also result in reduction of oxygen level and increase the incidence of algal bloom in the culture medium, which subsequently in extreme cases, lead to mortality of fish.

- Flooding of ponds: One of the major impacts of climate change in the brackish water zone of Niger Delta is excessive flooding (Table 7). This is a situation where rearing ponds are partially or completely submerged under water for a period of time, this phenomenon leads to the escape of stocked fish, which will bring loss to the farmers (Figure 3).

- Increase in water turbidity and heavy siltation of ponds: Consequent of rise in sea level as a result of climate change, there is turbulence action in waters found in this zone, this leads to increase turbidity of water, that flows into the pond at high tide, after some time, the sediments in the water column, will settle at the pond bottom, which results in quick build up of silts, thereby enhances the pond siltation, and thereby making the ponds shallower and unsuitable for fish culture.

- Introduction of new species and refuse wastes: Climate change in the coastal areas will results in increase soil erosion, which will lead to introduction of some new species i.e. both flora and fauna into the area. For instance in recent times, new species such as Nypa palm and some refuse wastes were reported in some fish farms located in Buguma and Degema area of Rivers State (Figure 4) which in time past has not been observed (Akinrotimi, 2012).

- Collapse of pond dyke and sluice gate: In the coastal areas of Niger Delta, the tidal water, which flows into the ponds, excrts much pressure on the pond components such as dykes, and sluice gate as a result of tremendous increase in sea level. This phenomenon has led to broken dykes and collapsed sluice gates in many fish farms located in the brackish water environment (Figure 5).

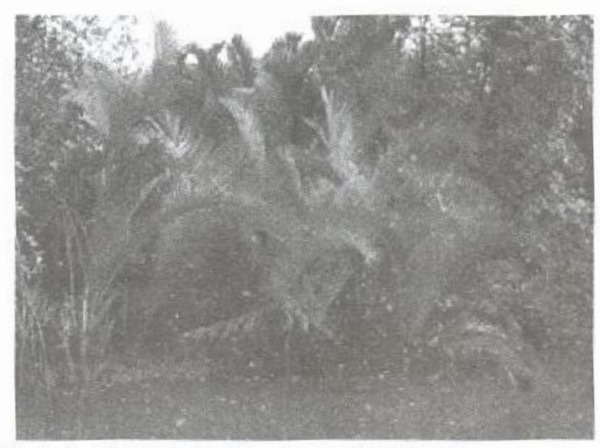

Plate 1: Non-spore forming L. plantarum.

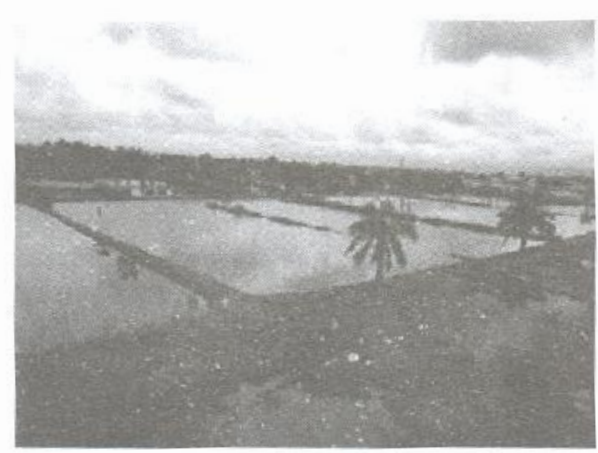

Fig. 4: Nympa palm observed in some fish farm in Niger Delta coastal areas.

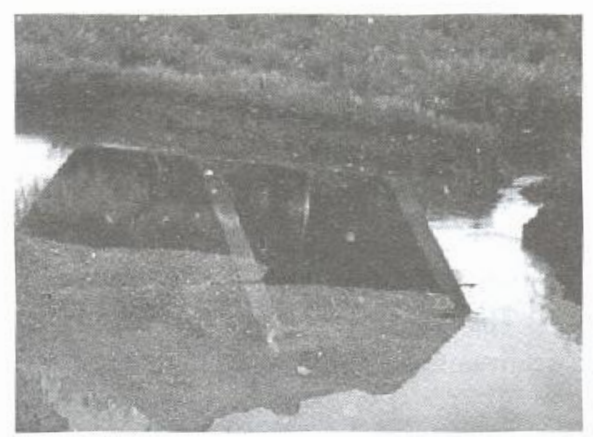

Soutce: Field Surzey (2013).

Fig. 5: Collapsed sluice gates and dykes consequent of climate change. 
- Fluctuations in salinity levels variations: Recently, there has been a variation in the levels of salinity in the coastal areas which has adversely affected the culture of fish in this zone. In the areas that are close to the sea, the salinity levels have increased, consequent of sea water incursions into these areas, where in areas far from the sea the salinity becomes usually too low, making it unsuitable to eulture some species of fish (Akinrotimi, 2012).

\section{Adaptation and Mitigation Strategies to Climate Change in Aquaculture}

The term adaptation and mitigation are two important terms that are very crucial in the climate change debate. Adaptation has been defined as adjustment in natural or human systems in response to actual or expected climatic change or their effects. While mitigation tackles the causes of climate change, adaptation tackles the effects of the phenomenon (IPCC, 2001). Some of the adaptation and mitigation strategies are highlighted below:

- Reduction in human activities: Human activities such as gas flaring should be reduced drastically to minimum possible level, so as to minimize the impact of climate change in the region. Government should begin the process of implementing policies to reduce the emissions of green house gases, through oil cxplorative activities.

n Good Site Selection: Good site should be selected when establishing a fish farm, low lying areas prone to flooding should be discouraged. Also areas close to the sea and flood plains of a major river should equally be avoided

- Provision of shading materials: Shading materials such as palm fronds should be used to reduce the incidence of high temperature, and direct impact of sun induced by climate change in tank culture systems, so as to achieve optimum performance of fish in the culture medium (Figure 6).

- Raising of dykes and regular reinforcement: The dykes should be raised very high to about 4.0 to $6.0 \mathrm{ft}$, above the ground level so as to prevent fish from escaping during flooding. This will go a long way increasing availability food fish and increase yield (Figure 7 ).

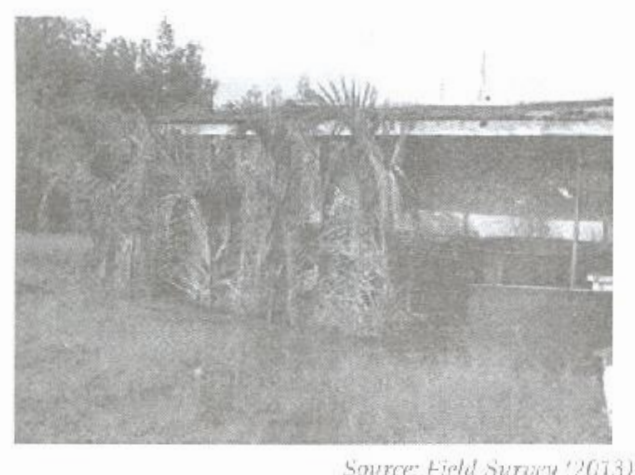

Fig. 6: Shading material to reduce impact of sunlight,

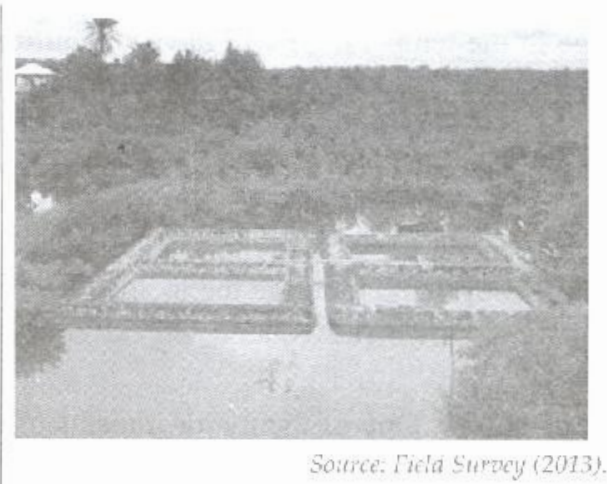

Fig. 7: An example of elevated dykes to control flooding in a fish farm.

- Effective management practices: Fish farmers should be encouraged to be more efficient in day to day management of their fish farms, with the use of better feed and should be more careful in handling of fish in culture medium so as to reduce the effects of excessive temperature, and also to desilt the pond bottom at lcast once in a year.

amprove monitoring and carly-warning systems: Government should improve weather monitoring and early warning systems across the country, so as $\omega$ give signal to fish farmers about impending climatic change, and the significance of climate change to the region ecosystem, so that there will be adequatc preparation on the part of the farmers on what to do to salvage the situation.

\section{Conclusion}

The effect of climate change on brackish water aquaculture in the corstal areas of Niger Delta is increasing. There is the need for government agencies and relevant institutions to come up with coordinated plans and policics that will ameliorate the cffects of climate on aquaculture production in Niger Delta. The context for which these policies can accommodate climate change and still addressing issues of poverty allsviation and food security across the region is urgent and crucial for the sus tainable development of aquaculture and achievement of millennium development gorals.

However, integrated approach policy should be adopted, in solving the issue of climate change, this approach should be recognized the effects of climate change on the local fish farmers and design an all-encompassing strategy to meet these needs. The approach should also take into consideration existing coping strategies of the local fish farmers to changes in thei: environment and build on them through policy formulation, with adequate participation of the fish farmers in the eorastal arcas 


\section{REFERENCES}

Akinro, A.O., Opeyemi, D.A., and Ologunagba, I.B. (2008). Climate Change and Environmental Degradation in Niger Delta Region of Nigeria: Its vulnerability, impacts and possible mitigations. Research Journal of Applied Sciences. 3 (3): 167-173.

(2012). Issues limiting the expansion of brackish water aquaculture in the coastal areas of Niger Delta. 169-178, $2 n$ : R.J Kolo and A.M. Orire (eds) Proceedings of the 26 th annual conference of the Fisheries society of Nigeria (FISON), Federal University of Technology, Minna. Niger State, Nigeria 28th November - 2nd December, 2011.

Abu O.M.G, Ansa, E.J. Edun O.M. and Gcorge, O.S. (2009b). Hacmatological response of Tilapia guineensis to acute stress. International Journal of Natural and Applied Science. 5(4): 338 - 343.

Abu, O.M.C and Aranyo A.A. (2011). Environmental Friendly aquaculture key to sustainable fish development in Nigeria Continental Journal of Fisheries and Aquatic Science 5(2): 17-31.

Abu, O.M.C., Ibemere, I.F, and Opara, C.A. (2009a). Economic viability and marketing strategies of pcriwinkle Tympanolonus fuscatus in Rivers State, Nigeria. International Journal of Tropical Agriculture and Food Systems 3(3): $338-244$.

Edun, O.M, Uka, A., Ogori, K. T., Mokayi, P.K. and Owhonda, K.N. (2010a). Public perception of mud skipper consumption in some fishing communities of Rivcrs In Ansa E. J, Fashina - Bombata H.A. and Ndimele P.E. (eds) Proceedings of the 25th Annual conference of the fisireries sucicty of Nigeria 25 29th October, 2010, Badagry, Lagos, Nigeria

Gabricl, U.U and Edun, O.M. (2010b). Effect of Climate change on aquaculture development in Nigeria. Journal for Applied Research 2(1):31-41.

Ansa, E.J. and Bashir, R.M. (2007). Fishery and culture potentials of the mangrove oyster (Crassosirea gasar) in Nigeria Reseurch Journal of Biological Sciences 2(4): 392-394.

Anyadike, R.N.C. (2009). Climate change and sustainable Development in Nigeria, conceptual and empirical issues. Enugu forum policy paper 10. African Institute for Applied Economics, Nigeria

Anyanwu,P.E.,Gabriel, U.U.,A kinrotimi, O.A.,Bekibele,D.O and Onunkwo, D.N (2007).Brackish wateraquaculture, a veritable tool for the empowerment of Niger Delta communitics. Scientific Research and Fssay 2(8):295-301

Ashton-Jones, N. J. (1998). The Human Ecosystems of the Niger Delta., Benin $\square$ Nigeria

Ayc, K. M. Ko, L.H, Win, H. L and Desilva, S.S. (2007). A new Fresh Water aquaculture practice that has successfully targcted a niche export market with major positive societal impacts: Myanmar. Aquaculture Asia XII (4): 311 - 324

Cummins, V., Mahong, C.J. and Connolly, N. (2005). Review of Integrated Coasial Zone Management and Principais of Best Practice coastal and marine resources center, Environmental Research Institute, University College, Cark, Ireland. 102pp.

Desilva, S.S. and Soto, D (2009). Climate change and aquaculture potential adaptation and mitigation. In K. Cochrane C. De Young, D. Soto and $\mathrm{T}$ Bahri (eds). Climate change implications for fisheries and aquaculture, overview of current scientific knowledge. FAO Fisheries and Aquaculture Technical paper No. 530 Rome FAO, Pp. 151-212.

Ezenwa, B.I (2006). Aquaculture research and tish farm development potentials in the Niger Delta. Paper presented at a workshop or Niger Delta Fishery training workshop: catch your fish 18-19 th $^{\text {th }}$ ay, 2006 Port Harcourt, River State, Nigeria $27 \mathrm{pp}$.

Idowu, A.A., Ayoola, S.O., Opele, A.I. and Ikenweiwe, N.B (2011). Lmpact of climate in Nigeria Iranica Journal of Energy and Environment. 2(2): 145-152.

Ifeanyi-Obi, C.C., Ituk, U.R. and Jike - wai, O. (2012). Climate Change effects and adaptations strategies, implication fur agricultural extension system in Nigeria. Greener Journal of Agricultural Sciences 2(2): $53-60$.

IPCC (2001). Inter Government Panel on Climatc Change. Climate Change and Biodiversity. In H. Gitay, A Suarez, R.T Watson, D.J Dokken (eds) IPCC Technical Paper. 76pp.

(2007). Climate change 2007: Synthesis report, Inter - Government Panel on Climate Change Available at www.pcc.ch/pdS' assessement -report/or4/syr/ar4-syr-tpoic/pdf. Accessed on 17th July, 2013

James, G. K., Adegoke, J. O., Saba, E., Nwilo, P. \& Akinycde, J. (2007). Satellite-Based Assessment of the Extent and Changes in the Mangrove Ecosystem of the Niger Delta. Marine' Geodesy, 30, $249-267$

James, G.K. (2008). Assessment of Environmental Change and Its Socio-Economic Impacts in the Mangrove Ecological Zone of the Niger Delta, Nigeria. Doctor of Philosophy, University of Missouri

Jamu, D.M and Ayinla, O.A (2003). Potential for the development of Aquaculture in Africa. NAGA Quarterib 26 (3):9-13.

Kay, R. and Alder, J. (2005). Cocasial Planning and Management. Francis and Taylor Publishing Group, New York, USA. 261 pp.

Lomburg, B. (2007). The skeptical envirunmentalist: measuring the real estate of the world. Cambridge, UK Cambridge University Press, $511 \mathrm{pp}$.

Mangut, J. and Egbcfo, D.O. (2010). The Fourth Republic and National Integration in Nigeria, 1999 2009. Aboki Publishers, Makurdi Benue State, Nigeria $178 \mathrm{pp}$. 